\title{
The Pastoral Use of the Book of Revelation in Late Tudor England
}

\author{
by PATRICK J. O'BANION
}

Over the past forty years historians have demonstrated continued interest in tracing the development of radical early modern English apocalypticism. The Tudor and Stuart eschatological scene, however, encompassed more than just millenarian activism. This article emphasises the pastoral ends to which Revelation was used by a group of late sixteenth-century writers as they sought to make it accessible to the 'common sort' of Christian. Viewing interest in the Last Days through this pastoral lens highlights both the tense complexities present in the Elizabethan Church and the usefulness of eschatological themes in studying ordinary and normative aspects of religious experience.

\section{${ }^{6} \mathrm{I}$} know thy works and thy love, and service, and faith, and thy patience, and thy works; and that they are more at the last then at the first.' In I582 a group of locals painted these words, the beginning of the letter to the angel of the church at Thyatira from the second chapter of Revelation, on either side of the royal arms in St Mary's church in Bury St Edmunds. ${ }^{1}$ Why was this act carried out and what was its significance? Clearly there was method to the madness of these eschatologically-minded church redecorators, for it was a carefully chosen squib. Thomas Gybson, a printer of the books of the separatist Puritan Robert Browne, had initially begun painting the words of Christ to the Laodicean church. Therein Jesus warned that he would spew the Laodiceans out of his mouth because their works were

The author wishes to express his thanks to Richard Kieckhefer for introducing him to George Gifford; to Charles H. Parker, James Hitchcock and Diarmaid MacGulloch who offered advice at various stages; to the helpful staff of the Folger Shakespeare Library where much of the research for this project was carried out; and to the members of the Folger Institute's 2004 English Reformation seminar for their criticism and encouragement.

1 BL, ms Lansdowne 36, no. 65. See John Craig, Reformation, politics and polemics: the growth of Protestantism in East Anglian market towns, I500-I6IO, Aldershot 200I, I04-5; Diarmaid MacCulloch, 'Catholic and Puritan in Elizabethan Suffolk: a county community polarises', Archiv für Reformationsgeschichte lxxii (I98I), 274; M. M. Knappen, Tudor Puritanism: a chapter in the history of idealism, Chicago I939, 26I-2; and John Strype, Annals of the Reformation under Elizabeth, Oxford I821, iii/I, I76-7. 
'neither hot nor cold' but 'lukewarm'. As Gybson began to write the phrase, however, he was 'stayd by advyce' and instead the other quotation was inscribed. $^{2}$

The epistles to Thyatira and Laodicea are the fourth and seventh of Christ's Letters to the Seven Churches in the book of Revelation, which discuss the condition of contemporary congregations in Asia Minor, encourage repentance, warn against sinfulness and recognise faithfulness and faithlessness. By comparison with its fellows, the letter addressed to Thyatira is relatively encouraging. There is a significant sense of optimism in it, for the church's 'last' works are better than its 'first'. But although Thyatira is commended for its increasing godliness, there are troubles as well. The letter continues: 'Notwithstanding, I have a few things against thee, that thou sufferest the woman Jezebel, which maketh herself a prophetess, to teach and deceive my servants; to make them commit fornication, and to eat meat sacrificed unto idols.'

Since the angel to whom the letter is addressed is often thought to represent the congregation's minister, this event could be interpreted as an attack upon the minister of St Mary's church. Perhaps he was being lured away from the pure faith by some modern-day Jezebel. Yet John Strype says of the act that the minister 'permitted it to be done'. ${ }^{3}$ And in general the inhabitants of Suffolk were strongly committed to the men who 'spen[t] themselves among their severall flockes and charges'. ${ }^{4}$

More likely the squib was an indictment of Elizabethan Anglicanism and of the monarch herself. As the alteration of the royal arms indicates, the idolatrous Jezebel was surely Elizabeth who, in spite of being the supreme governor of a national Church in the Reformed tradition, had long kept a crucifix in her private chapel and restrained the Church from further reformation. If the Laodicean Jezebel was Elizabeth, then the bishops and their lackeys were those who refused to repent of their adultery with her and their submission to her. Gybson and his associates saw themselves as unwilling to partake in such idolatry. Such an aggressive propagation of a theology of the remnant suggests great uncertainty about the present state of the established Church in the 'primitive Puritan commonwealth' of late sixteenth-century Suffolk. ${ }^{5}$ The striking combination of reforming sympathies, lay support for local clergy, the critique of the state of the established

2 MS Lansdowne 36, no. 65.

${ }^{3}$ Strype, Annals of the Reformation, I77.

${ }^{4}$ Robert Allen, The doctrine of the Gospel by a plaine and familiar interpretation of the particular points or articles thereof, London I6o6 (RSTC 364$)$, sig. 4-5. J. S. Cockburn notes that in the same year 'fourteen principal men out of Suffolk' sought leniency for their nonconforming ministers from the judges at the summer assize: A history of English assizes, ${ }_{55}^{8-I 7 I 4}$, Cambridge I972, 199-206. Patrick Collinson points out that the laity of the region regularly provided for their ministers in their wills: Godly people: essays on English Protestantism and Puritanism, London 1983, 452-3.

${ }^{5}$ Collinson, Godly people, 449. 
Church and even of the monarch is interesting in its own right but the use of language set in an apocalyptic context suggests just how complicated the religious culture of England had become by the end of Elizabeth's reign.

This article examines the interplay between these themes in the eschatological literature of the late Tudor and early Stuart era by analysing a group of writings whose authors intentionally sought to make the book of Revelation accessible to the 'common sort' of believers. It will emphasise the pastoral focus of these eschatological works, an element that is often overlooked by historians. The significance of discussions about the End Times in early modern England does not lie only in their contributions to the Civil War, the execution of Charles I and in their production of remarkable millenarian movements like the Fifth Monarchy men. They are also important because they offer insight into the ordinary and normative religious milieu of the age.

For many decades historians characterised the middle of the seventeenth century as having been awash with irrational eschatological expectations, fanatic chiliastic sects and frightening instantiations of apocalyptic zeal run amok. ${ }^{6}$ Recently, however, scholars have argued with increasing frequency that apocalyptic expectations were a much more pervasive and rational component of seventeenth-century English life than had previously been believed. ${ }^{7}$ As a result, they have traced the roots of radical seventeenthcentury English apocalypticism back into the sixteenth century and beyond, examining its continental (i.e. Joachimite, Hussite and Evangelical) and indigenous (i.e. Lollard) sources. This etiological approach, however, has fostered a tendency to emphasise almost exclusively the individuals and events that paved the way for those radical developments, that is, the progenitors of chiliasm and apocalyptical activism. Even the authors who have deliberately focused on the sixteenth century tend to view it as part of a tradition developing toward radicalism. ${ }^{8}$ Although this approach has been

${ }^{6}$ George N. Clark, The later Stuarts, I660-I7I4, 2nd edn, Oxford I956, 22; G. P. Gooch and H. J. Laski, English democratic ideals in the seventeenth century, New York 1959, 225; Herschel Baker, The wars of truth, Cambridge, MA 1952, 85; L. F. Solt, Saints in arms: Puritanism and democracy in Cromwell's army, Stanford, $\mathrm{C}_{\mathrm{A}}$ 1959, 73; Norman Cohn, The pursuit of the millennium: revolutionary messianism in medieval and Reformation Europe and its bearing on modern totalitarian movements, London I96I, 305; H. R. Trevor-Roper, Religion, the Reformation and social change, London I967, 286 and n. 365 .

7 William Lamont, Godly rule: politics and religion, I603-166o, London I969, I3; B. S. Capp, The Fifth Monarchy men: a study in seventeenth-century English millenarianism, Totowa, NJ I972, I6, 238; Christopher Hill, AntiChrist in seventeenth-century England, Oxford 1971, 25; Tai Liu, Discord in Zion: the Puritan divines and the Puritan Revolution, I640-I660, The Hague I973.

8 Bryan Ball, A great expectation: eschatological thought in English Protestantism to I66o, Leiden I975; Paul Christianson, Reformers and Babylon: English apocalyptic visions from the Reformation to the eve of the Civil War, Toronto 1978; Katharine R. Firth, The apocalyptic tradition in Reformation Britain, I530-I645, Oxford 1979; Crawford Gribben, The Puritan millennium: literature and theology, I550-I682, Dublin 2000. 
fruitful it has also, by virtue of its interests, emphasised one particular aspect of the role played by the Last Days in early modern England.

A rather different but particularly striking element of the late Tudor eschatological scene is the authorial emphasis placed on granting the common people access to the book of Revelation by making its meaning 'playn and easye' for them to comprehend. ${ }^{9}$ It was in this tradition that Arthur Dent declared, in the last year of Elizabeth's reign, that he was

not ignorant that some would not have this booke medled withall, nor in any wise to be expounded among the common people, because (say they) it is so darke and hard to understand. But let all such leave their owne opinions, and hearken what the holy Ghost saith, Blessed is he that readeth, and they that heare the words of this Prophecy, EDc. What can be said more? ${ }^{10}$

Dent's assertion was an echo of the sentiments of earlier writers, who for some decades had emphasised both the perspicuity of Revelation and the necessity of communicating its message to the masses.

These 'playn and easye' authors stand in contrast to a second group whose writings on John's Apocalypse were, at least initially, intended for a much more educated audience and who propagated increasingly sophisticated and often very speculative interpretations of the book. John Napier, for example, used complex mathematical formulae to uncover the real meaning of Revelation. In Joseph Mede's Clavis apocalyptica both first-class philological skills and fully developed millenarianism walked hand in hand. ${ }^{11}$ One needed a considerable background in mathematics, linguistics and history to follow the apocalyptic publications of writers such as Napier, Mede or Thomas Brightman. $^{12}$

This article analyses a number of works that appeared at the end of the Tudor and the beginning of the Stuart period: the English translation of Heinrich Bullinger's A hundred sermons upon the Apocalips of Jesu Christe,

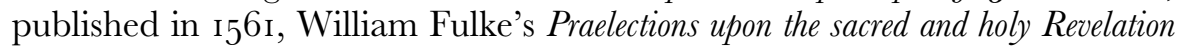
of Saint John, translated from Latin in ${ }_{5} 573$, George Gifford's 1596 Sermons upon the whole booke of the Revelation and Thomas Cartwright's A plaine explanation of the whole Revelation of Saint Fohn, composed before the author's death in 1603 but published posthumously in I622. These four writers produced works of pastoral theology. Their books were specifically marketed to the 'common sort' of Christians and to pastors who desired to preach to such people effectively. The writers and their editors and translators actively sought to comfort their audience in its present afflictions by using Revelation as a pastoral tool rather than as a device to unlock future mysteries.

9 William Fulke, Praelections upon the sacred and holy Revelation of Saint fohn, London ${ }_{573}$ (RSTC I I443), sigs 3r-4v. ${ }^{10}$ Arthur Dent, The ruine of Rome, London i6o3 (RSTC 6640), fo. A3v.

${ }_{11}$ Joseph Mede, Clavis apocalyptica, Cambridge 1632 (RSTC 17767).

12 Katharine Firth traces these developments in The apocalyptic tradition, I79. 
For comparative purposes this study will also examine three additional works. Two of them, John Napier's I593 A plaine discovery of the whole Revelation of Saint Fohn and Arthur Dent's The ruine of Rome, first published in I6o3, appropriate the 'playn and easye' rhetoric but they represent a significant departure from the others in emphasis and focus. The third, The Apocalyps, or Revelation of S. Iohn the Apostle and Evangelist of our Lord Iesus Christ by François du Jon (Franciscus Junius), a late sixteenth-century continental import to England, first translated in I596, exhibits some of the same concerns as the 'playn and easye' writers but is born of a very different context.

Heinrich Bullinger (I5O4-75), Zwingli's successor at Zurich, first preached his sermons on the Apocalypse to his congregation between I 555 and I556. Among those in attendance were English exiles, recent arrivals seeking safe harbour in the wake of Mary's accession. Neither Zwingli, Calvin, Bucer nor Vermigli wrote a systematic study of Revelation and so Bullinger's commentary was the most important early exposition of the book from a Reformed perspective. It was translated from the Latin by John Daus of Ipswich in 156 I and was reprinted in 1573 .

William Fulke (1538-89) was a Puritan controversialist, sometime Fellow of St John's College, Cambridge, and, from 1578, Master of Pembroke College. His In sacram divi foannis Apocalypsim praelectiones, which derived from university lectures given on the book, were published in 1573 and were translated into English by George Gifford with a brief introduction in the same year. ${ }^{13}$ Fulke's words, unlike Bullinger's, were not preached, at least not in their published form. It is possible that his commentary was connected to a series of sermons on Revelation since, after being temporarily expelled from Cambridge for leading an anti-surplice protest among the students, he spent the years from 1569 to 1578 as chaplain to the earl of Leicester. ${ }^{14}$ He is known to have preached a sermon at Hampton Court on I2 November 1570 in which he 'playnly proved Babylon to be Rome', taking the fourteenth chapter of Revelation as his text. ${ }^{15}$

The translator of Fulke's work, George Gifford, was a student at Christ's College, Cambridge, probably between ${ }_{5} 56$ and ${ }_{5} 573$, receiving both a bachelor's and a master's degree. Although his time at Cambridge does not appear to have overlapped with Fulke's, Gifford was clearly impressed by the

13 The work was originally composed in Latin, which edition was printed on 3I December I573 (RSTC II442). The English edition simply bears the date I573. Since the new year began on 25 March, it is likely, but not certain, that the English edition actually went into print before the Latin.

14 See Harry Culverwell Porter, Reformation and reaction in Tudor Cambridge, Cambridge I958, I19-35; Peter Lake, Moderate Puritans and the Elizabethan Church, Cambridge 1982, 57-8; and Timothy Scott McGinnis, George Gifford and the Reformation of the common sort: Puritan priorities in Elizabethan religious life, Kirkville, Mo 2004, 27-8.

${ }_{15}$ William Fulke, Wherein is playnly proved Babylon to be Rome, both by scriptures and doctors, London I570 (RSTC i $4449 \cdot 5)$. 
former don's Puritan sensibilities and incorporated a good deal of Fulke's exegesis into his own Sermons upon the whole booke of the Revelation published first in 1596 and then twice in I599. Gifford preached through the Apocalypse at least twice to his congregation at Maldon, Essex, where he served from I580 first as curate to the vicar, then as vicar in his own right, and finally, after being deprived of his living, under the auspices of a privately endowed lectureship.

A plaine explanation of the whole Revelation of Saint Fohn by Thomas Cartwright (I535-I603) was published posthumously in I622, probably as a result of the efforts of John Dod and Arthur Hildersham. ${ }^{16}$ As the anonymous writer of the introduction notes, however, it was a work upon which 'the Author (a man of excellent gifts) [had] long since travailed; and now by the providence of God, are his labours in this kinde published for our comfort ${ }^{17}{ }^{17}$ Exactly when the travailing occurred and to what end it was intended is obscure but it is not the only one of Cartwright's works to be published after his death. ${ }^{18}$ The title page does not list the controversial Presbyterian as the author, calling him only a 'faithfull Preacher', but Thomas Cartwright's name was entered in the Stationers' Register on 26 August i622. Whether Cartwright ever intended the commentary to be published is also uncertain. The editor describes it as having been written 'for more private use, and now published for the further benefit of the people of God'. ${ }^{19}$

In addition to demonstrating a significant interest in the book of Revelation, all of these writers and editors-except for Bullinger, of course - were part of the mainstream of late Elizabethan Puritanism. Yet Bullinger's friendship was cultivated by Marian exiles and many of those who sought an ongoing reformation of the Church under Elizabeth. He, Cartwright and Fulke were involved in the Vestiarian controversy although the Englishmen were not on the same side as Bullinger, a tribute to the way in which his authority was to be appropriated by different factions within the English Church. Cartwright and Gifford were active in the classical movement. All three of the English authors spent time at that Puritan hotspot, the University of Cambridge. Daus, Fulke and Gifford shared a common geographical base in East Anglia, a region known for its prophesyings, gatherings of Reformed-minded ministers and lay people for bible study and preaching. And John Parkhurst, the Puritan bishop of Norwich from 1560 to 1575 , was a personal friend to Bullinger and

${ }^{16}$ Elizabethan nonconformist texts, I: Cartwrightiana, ed. Albert Peel and Leland H. Carlson, London I951, 6-9.

17 Thomas Cartwright, A plaine explanation of the whole Revelation of Saint Fohn, London 1622 (RSTC 4710.5), fo. A2v.

${ }^{18}$ For example, idem, Plaine and familiar exposition of the ten commandements, London 1604 (RSTC 6968); Commentary vpon the epistle of Saint Paule written to the Colossians, London i612 (RSTC 4708); and Treatise of Christian religion, London ${ }_{16} 6$ ( 6 (RTC 4707.7).

${ }^{19}$ Idem, A plaine explanation, sig. I. 
encouraged translations of the Reformer's works. The writers were well connected at court. Robert Dudley found livings for both Fulke and Cartwright when theological controversy left them unemployed. Gifford dedicated his commentary to Dudley's son-in-law, Robert Devereux, earl of Essex, and received support from William Cecil and Francis Knollys when he lost his living at Maldon. Cartwright, Fulke and Gifford suffered under Whitgift's Puritan crackdown but none of them sought to leave the established Church. Cartwright and Gifford in particular strongly opposed the separatist tactics of the Brownists.

It is not apocalyptic expectation but a pastoral sensibility that distinguished these 'playn and easye' publications from other Tudor and early Stuart eschatological writings. For the authors and editors of that pastorally minded group, Revelation was a book that could easily and should definitely be made accessible to the 'common sort' of people. For that reason, its exposition was not intended to be merely an intellectual enterprise but rather an opening up of its contents, a literal revealing of its mysteries, in such a way that readers were spiritually nourished and ministers were instructed in the most useful way to preach the text to their congregations. Thus Bullinger asserted that 'it shal be the part of the preacher to have a respect chiefly to such thynges as make both for the plaines of speache, that he may be under[stood], even of the grossest sort: and also for the edifyeng of the audience, that he brynge nothyng, that shuld little profit'. Rather, the preacher was to 'applye these things to the edifieng of the church where he is, having consideration of the place, time and persons: yet alwayes observing the true sence of the boke or of Gods words'. ${ }^{20}$

Likewise, Gifford's dedicatory epistle to Fulke's Praelections noted that he would not be 'over tediouse' in his description of the book since the reader would easily be able to follow the author's own arguments. In Gifford's opinion, Fulke wrote 'briefelye and playnly', not concerning himself with 'long circumstances' or 'darcke misteries' but rather with making 'those thinges that seemed most darcke and difficulte to be understood ... playn and easye'. ${ }^{21}$ The anonymous editor suggested that the value of Cartwright's commentary lay specifically in its being 'more briefe and plain upon the whole Book then any other' and that it was therefore 'more usefull for the most, that have most use of it'. ${ }^{22}$

That in the case of Cartwright and Fulke, it was not the authors themselves but the editor and translator who emphasised the accessibility of the work to the 'sympler sort' demonstrates the cachet attached to such a designation even into the i62os. If, for example, Fulke was appropriated by a man like

${ }^{20}$ Heinrich Bullinger, A hundred sermons upon the Apocalips of Jesu Christe, London ${ }_{5} 6 \mathrm{r}$ (RSTC 406r), fo. B6v. Note also Irena Backus' emphasis on the pastoral nature of Bullinger's work on Revelation in her Reformation readings of the apocalypse: Geneva, Zurich and Wittenberg, Oxford 2000, I03. $\quad{ }^{21}$ Fulke, Praelections, sigs 4-5. $\quad{ }^{22}$ Cartwright, A plaine explanation, fo. A2r. 
Gifford to support his programme of educating the common people, it was because the Praelections exhibited the same pastoral emphasis that characterised his own career. ${ }^{23}$ Even authors whose writings clearly were not plainly written or easy to understand attempted to cast them in such a way as to suggest that they were. Thus, both Arthur Dent and John Napier sought to present their writings as accessible to the person in the pew, even as they required their readers to follow complex mathematical calculations and tortuous historical analyses in order to enter into the mysteries of Revelation.

To make their work accessible to the 'common sort', the 'playn and easye' authors wrote straightforwardly and in a style that would be understandable for readers with little theological education. Gifford's and Bullinger's works were collections of preached sermons, although in the case of Bullinger some evidence exists that his sermons were slightly altered for publication. ${ }^{24}$ The authors resisted delving too deeply into 'violent wrestings, and long digressions far from the pourpos' that 'deserve no prayse in preachynge'.25 Fulke's and Cartwright's works were never preached, at least not in their published form. They were instead commentaries that explained each verse in detail using simple language. Cartwright's A plaine explanation in particular was very short and avoided long words and complicated or speculative interpretations of symbols. This careful focus on expounding the entire book in a simple manner contrasts with seventeenth-century writers like Brightman or Mede and even with Dent or John Bale in the sixteenth century whose expositions of the Apocalypse were much more thematically driven. And, while their speculative interpretation of apocalyptic imagery was perhaps more interesting, their writings were certainly much more difficult for those with limited education to follow.

The fact that the 'playn and easye' writers and editors thought that Revelation should be made available to the 'common sort' presupposes that they believed their readers could understand it, that is, that the book could be made sense of in a relatively straightforward manner. This was not a foregone conclusion. Centuries earlier, the church Father Irenaeus had admitted great difficulty in interpreting the book. 'Shall the unlearned

${ }^{23}$ Gifford's focus on the 'common sort' is present in almost every one of his publications. See, for example, A brief discourse of certaine points of the religion, which is among the common sort of christians, which may be termed the countrie divinitie, London I58I (RSTC I1845); Dialogue betweene a papist and a Protestant, applied to the capacitie of the unlearned, London I582 (RSTC I1849); $A$ catechisme conteining the summe of christian religion giving a most excellent light to all those that seeke to enter the path-way to salvation, London $\mathrm{I}_{58}$ (RSTC I1848); and $A$ dialogue concerning witches and witchcraftes, London 1593 (RSTC i 1850). See Dewey D. Wallace, Jr, 'George Gifford, Puritan propaganda and popular religion in Elizabethan England', Sixteenth Century Fournal ix (1978), 27-49. Along similar lines Scott McGinnis has discussed the pastoral characteristics of Gifford's theology in George Gifford, esp. pp. I-24, IIO-34.

${ }^{24}$ Bullinger, A hundred sermons, fo. B6v.

25 Ibid. 
people', Gifford wondered, 'be made to understand that which that learned Father could not attaine unto?' Indeed, yes. He believed, as Bullinger had previously stated, that once the symbolic events in Revelation had been fulfilled, the book became 'simple and playne to the faithful, that wil read it attentively \& with devotion ' ${ }^{26}$ Hence Gifford explained that 'such things as were fulfilled in the dayes of the learned fathers were cleare unto them. The things to come they could not understand for the most part, but did grope at them. These are now fulfilled in our eyes, and are manifest, at the least most of them'. ${ }^{27}$

This sense of the perspicuity of Revelation and the desire to open its contents to readers spurred the 'playn and easye' authors to resist speculative interpretations. Thus Cartwright, reflecting on the Number of the Beast, refused to follow Irenaeus' suggestion that 666 was the numerological equivalent of the Greek word $\lambda$ áteıvos because that interpretation was 'too Cabalisticall' ${ }^{28}$ Likewise, he would not assign a direct contemporary equivalent to the apocalyptic enemies of God, Gog and Magog. 'Here is not meant', he explained '(as some doe imagine) any particular Country of Germany, England, \&c .... But here onely is meant, those most bitter enemies of the Church ... [that] shall come with all might and malice that can be, and shall fight against the Church, compassing about it to destroy it. ${ }^{29}$

While Bullinger, Fulke and Gifford might disagree with Cartwright about what exactly it meant to be 'too Cabalisticall' or too speculative, they do agree with him in principle. Gifford for example - who with Bullinger and Fulke accepts the $\lambda$ áteıvos interpretation of the Number of the Beast and identifies Gog and Magog as Islam and the papacy ${ }^{\mathbf{3 0}}$ - moves quickly from the specific interpretation of a visionary image to its implication for his parishioners. Thus, he explains that the twenty-four elders of Revelation xi 'do represent all the Saints, both of the auncient Church, as also under the Gospell' but this interpretation does not lead to further speculation about the meaning of the vision but rather to a discourse against the Roman Catholic doctrine of the saints. ${ }^{31}$ The vision of the martyrs dressed in white under the heavenly altar segues into an opportunity to discuss the doctrine of salvation. ${ }^{32}$ The fall of Babylon the Great becomes a discourse on the Christian duty of magistrates, ministers and laity to oppose the enemies of the Gospel, the political, theological and lay supporters of the papacy. ${ }^{33}$

26 Ibid, fo. B3v.

27 Ibid. 8. See also, to the same effect, A plaine explanation, 7, and Praelections, fo. I49v.

28 Cartwright, A plaine explanation, 85. $\quad{ }^{29}$ Ibid. I24-5.

30 Bullinger, A hundred sermons, fo. Bir and pp. 6o9-io; Fulke, Praelections, fos 89v, I33v; Gifford, Sermons upon the whole booke of Revelation, London I596 (RSTC i 1867), 263-4, 398.

${ }^{31}$ Giffford, Sermons upon the whole booke of Revelation, II7, in8.

${ }^{33}$ Ibid. $340^{-2}$. 
A related characteristic of this pastoral approach is the use of Revelation as a source of comfort for the present sufferings of readers rather than as a tool for descrying the future or even for unlocking the meaning of the past. Thus Bullinger maintains that 'we oughte not to suffer that the Churche, and the symple people afflycted and tempted in the same shulde want that comfort, admonition, and doctryne, which in tymes past the lord Jesus himselfe by S. John, hath prepared for these hard things \& times, by revealing this Apocalips ${ }^{34}{ }^{34}$ And similarly, when treating Christ's declaration, 'Behold I come quickly', Fulke does not speculate on the nearness of the saviour's return but rather that 'in the meane time' Christ gives to Christians the 'doctrine of this prophecie ... as a passing great treasure, whose wordes if they will diligently imprinte in mind, \& kepe them so imprinted, he pronounceth that they shal be blessed ${ }^{35}$ Repeatedly these authors make pastoral application the interpretive focus of the apocalyptic visions.

This approach stands in subtle but significant contrast to that of Dent or Napier. For Dent the blessing of the book of Revelation is that it tells what will come to pass in the future, specifically the fall of Rome. 'What can be more ioyfull or comfortable to all the people of God', he wonders, 'then to know afore-hand that Babylon shall fall: Rome shall downe: Antichrist the great persecutor of the Church, shalbe utterly confounded and consumed in this world. ${ }^{36}$ Likewise, for Napier, who was a gentleman scholar, not a pastor or a professional theologian, Revelation is a book that unlocks both the past and the future because it is a book that, to the properly enlightened interpreter, provides the date of Christ's return - somewhere between I688 and I70o, probably I697 or I699. ${ }^{37}$ His complex mathematical calculations and involved historical analyses are meant, according to the author, to be a great benefit to readers. Napier explains that he "was constrained to compassion, leaving the Latine, to haste out in English this present worke, almost unripe' for the sake of the simple. ${ }^{38} \mathrm{He}$ does not, however, seek to comfort his readers in their day-to-day lives, only in their apocalyptic future.

The treatment of the First Vision, and in particular the Letters to the Seven Churches in chapters ii and iii, is a meaningful indicator of the way that Revelation is approached by a particular author. In the midst of a book containing seven-headed, ten-horned scarlet beasts ridden by blood-drunk harlots robed in purple, the letters appear banal by comparison. They are precisely the sort of thing that readers and commentators tend to pass over quickly as they move on to explore the mysterious symbolism of the later

34 Bullinger, A hundred sermons, fo. B6r-v.

35 Fulke, Praelections, fo. I48r.

36 Dent, The ruine of Rome, fo. A4v.

37 John Napier, A plaine discovery of the whole Reuelation of Saint Iohn, Edinburgh I593 (RSTC I8354), I6-22.

38 Ibid. fo. A6v. 
chapters. Yet for authors seeking to draw on pastoral themes, the first three chapters offer a great deal of useful content.

The First Vision comprises about $12 \cdot 5$ per cent of Revelation, but the 'playn and easye' commentators spend an inordinate amount of time expounding it. Bullinger commits just under 20 per cent of his book and more than a fifth of his sermons to it. It takes up nearly i6 per cent of Cartwright's brief A plaine explanation and over i7 per cent of Fulke's Praelections. George Gifford assigns almost one quarter of his book to the subject. By contrast John Bale's Image of both churches devotes only 8.5 per cent to the First Vision and Arthur Dent and John Napier give it just io per cent. Joseph Mede hardly deals with that section of the book at all, mentioning it only in passing, and revealingly Mede's illustration of the book, his visual chart of Revelation, has no place for the letters.

Thomas Brightman's Revelation of the Apocalyps, first published in English in I6II, is the proverbial exception that proves the rule. For a member of the more sophisticated and speculative approach, Brightman spends a surprising amount of time exegeting the First Vision: just under i9 per cent. Yet his reason for devoting so much attention to it is altogether different from the 'playn and easye' writers. Brightman takes each one of the Seven Letters to be a picture of a successive age within the Church. As he unpacks the language of the letters, he decodes them, suggesting an analogue for each letter to an era in the history of the Church militant. He concludes, in brilliant if suspect interpretative style, that the last three Churches represent the Lutheran, Reformed and English Reformations respectively. ${ }^{39}$ Like the eschatological redecorators of Bury St Edmunds, his association of the English Church with the Laodiceans who were neither hot nor cold but lukewarm caused Brightman trouble. It was largely for this reason that the book was published from the continent. As for deriving pastoral care from the Seven Letters, according to the author six of them were descriptions of other places and times. Ipso facto, nothing in them was directly applicable to the seventeenth-century English reader. And one is hard pressed to find much comfort in the letter to the Laodiceans. Brightman's desire to tease out hidden meanings from the Seven Letters and connect those meanings to specific events demonstrates the degree to which Revelation became for him a book about unlocking the past and the future rather than, as the "playn and easye' writers would have it, a book of comfort for the present.

39 Brightman's exegesis on these matters can be found in Revelation of the Apocalyps, Amsterdam i6ri (RSTC 3754) as follows: Ephesus=Apostles to Constantine (p. 34); Smyrna $=$ Constantine to Gratian (p. 48); Pergamum $=$ Gratian to I300 (p. 55); Thyatira $=\mathrm{I} 300-\mathrm{I} 520$ (p. 64); Sardis $=$ the Lutheran Reformation beginning in $15 \mathrm{I} 7$ under Luther (p. 77); Philadelphia = the Reformed Reformation beginning in 1523 with Zwingli (p. 9o); Laodicea = the English Reformation beginning in 1547 under Edward VI (p. I03). 
In spite of the limited amount of time that Napier and Dent spend on the first three chapters they clearly intend to present their work as part of that 'playn and easye' tradition. ${ }^{40}$ In fact, Dent's The ruine of Rome borrows freely from Gifford's sermons. ${ }^{41}$ Yet when Dent addresses the Letters to the Seven Churches their perspicuity actually becomes a reason for quickly passing over them. He explains that he has chosen 'in a generall and compendious maner to set downe the most speciall matters contained in them ... not meaning to insist upon every particular, both because these two chapters are plaine, and easie to understand, \& also because they have bene sufficiently beaten upon by many' ${ }^{42}$ This comment contrasts sharply with Dent's own assertion made earlier in his book that it is 'very needfull' for the whole of John's Apocalypse to be 'expounded againe and againe, and all the Lords people made throughly aquainted with it. For in this age wherein we live, this Prophesie can never be inough opened and beaten upon' ${ }^{43}$

What exposition Dent offers of the Seven Letters is virtually devoid of the pastoral emphasis so striking in the other writers. Promises made to the seven churches are for those churches and are not applied to contemporary Christians. Hence, 'Ephesus is promised, that if they fight it out couragiously and constantly to the ende, they should eate of the tree of life, which is in the middest of the paradise of God' ${ }^{\text {'4 }}$ and 'Smyrna is promised in the like case, that they should not be hurt of the second death [italics added]. ${ }^{45}$ Seemingly the only pastoral accommodation that Dent makes in this section is in his summation: 'Thus wee see what great and precious promises are made to all Churches that fight and overcome in this their spirituall batell and conflict. ${ }^{36}$ Yet even that statement merely highlights the complete lack of pastoral concern elsewhere in the chapter and, besides, the statement is a paraphrase lifted from Gifford. ${ }^{47}$

Although Dent harps upon the plainness of Revelation, it is for him a plainness that requires some significant intellectual groundwork. He consoles readers who have difficulty in understanding the book by noting that he arrived at his interpretation through a thorough familiarity with Moses, the Prophets, knowledge of antiquities, church history, and 'the particular state thereof in divers ages', 'the observation of phrases and maner of speech' used by Old Testament writers, the 'serious and deepe weighing of all the circumstances of the text, \& conferring one thing with another, consequents

\footnotetext{
40 For example, Napier, A plaine discovery, fos A5v, A6r-v, p. 270; Dent, The ruine of Rome, fos A3v, A4v-aar, aa3r-v, pp. I5, 86.

${ }^{41}$ Compare, for example, Dent, The ruine of Rome, 68, 8I-2, and Gifford, Sermons upon the whole booke of Revelation, $\mathrm{1} 33, \mathrm{I} 46-7$ respectively.

${ }^{43}$ Ibid. fo. aar. $\quad{ }^{44}$ Ibid. 36.

42 Dent, The ruine of Rome, 25.

47 Sermons upon the whole booke of Revelation, II3. Gifford's actual phrase is 'We have had also very worthy and precious promises set foorth to all that get the victory in the Christian battaile.'
} 
with the antecedents, \& the antecedents with the consequents'. And to all of the preceding he adds the 'knowledge of artes, tongues, and the learned writings, and interpretations of sundry excellent men'. ${ }^{48}$ After this litany, Dent has the temerity to ask his reader, 'Sith then there be so many helpes for the opening and expounding of this Revelation: why should any be discouraged from the reading and study thereof? ${ }^{49}$ Why indeed.

Like Dent's, John Napier's commentary claims to be accessible and plain. The very title, A plaine discovery of the whole Revelation of Saint Fohn, is almost identical to the one given to Cartwright's work nearly three decades later. In his letter 'to the misliking reader whosoever', Napier explains that his arguments are 'founded upon the most evident reasones, clearest tokens, and plainest scriptures, and thereafter every argument followes one another, from the plainer text, to the obscurer text, til the whole be discovered ${ }^{\prime}{ }^{50}$ In fact, Napier claims that he had initially intended his work to be published in Latin and to have been written at a much more leisurely pace. The attempted Armada invasion and the propensity of the unlearned to put more faith in 'Iesuites and seminarie Priests then in the true scripturs of God, and in the Pope and King of Spaine, then in the King of Kings' did 'so pitie our hearts' that Napier published his work quickly and in English that 'the symple of this Iland may be instructed' ${ }^{\mathbf{5}}{ }^{1}$

Napier's entire commentary drives toward unlocking the symbolism of Revelation as a means of interpreting the past and foretelling the future. His exposition presents the book as a history of the 'seven ages' of the Church, all but the final one lasting exactly 245 years, and he assigns specific dates to each of them. Thus, the author suggests that the seventh age, which began in I54I, was to come to an end in ${ }^{17} 76 .^{52}$ However, because Napier demonstrates that Christ would intervene in history before the end of the seventh age, he suggests that, 'the latter day will fall in An. Christi I688. Wherefore, appearinglie betwixt this 1688 yeare, according to the Revelation, and the I70o yeare, according to Daniel, the said latter day should fall ${ }^{53}$

Although Napier suggests that he intends his work to comfort his readers, it is, like Dent's, largely an apocalyptic comfort that he offers. Thus he emphasises that the papacy's power is in decline and that Protestantism is moving from strength to strength. He notes that 'the Antichristian \& Spanish flote is destroyed' and that 'the late King of France, Duke of Guize, \& his brother, Papists, \& committers of the Parisian massacre' are 'al murthered by other' and that 'a Protestant [is] nowe made king of France: so that before the ende of this Iubelie (God willing) Rome and the whol Papistical kingdome thereof, shal be ruined'. ${ }^{54}$ These are not, perhaps,

\footnotetext{
48 Dent, The ruine of Rome, fos $3 \mathrm{v}-4 \mathrm{r} . \quad{ }^{49}$ Ibid. fo. $4 \mathrm{r} .{ }^{50}$ Napier, A plaine discovery, 270.

51 Ibid. fo. A6v. $\quad{ }^{2}$ Ibid. I2. $\quad 53$ Ibid. 2I.
} 
insignificant comforts that he extends to English Protestants, but they are of a very different character than those offered by the 'playn and easye' commentators.

While those writers apply the message of Revelation to their parishioners as a source of spiritual comfort, Napier sees the book much more as a mystery to be solved. Like the extracts from the Sybilline oracles that he appends to his treatise (because they were neither 'so authentik, that hitherto we could cite any of them in matters of scriptures, neither so prophane that altogether we could omit them'), Revelation has little to say about the day-to-day spiritual struggles of his readers. ${ }^{55}$ He hopes that knowing that Christ will return in about a century will 'bring repentance and amendement' ${ }^{\text {'56 }}$ Yet the way in which he has 'paraphrastically expounded' the text and 'historically applied' it leaves little space for the application of pastoral edification. ${ }^{57}$

It is, of course, not the case that the 'playne and easye' commentators were simply concerned about comforting their readers in the midst of tribulation while the more speculative authors were trying to make a name for themselves or to profit economically. No doubt Napier and Dent as well as Brightman and Mede believed that they were properly exegeting the text. Those who published Bullinger, Cartwright, Fulke and Gifford presumably were seeking to profit financially as well as to succour the suffering sheep of Christ. And their writers certainly had an agenda. In addition to edifying the 'symple people' these learned clergymen were trying to turn their readers into dedicated and well-informed Reformed Protestants just like themselves. ${ }^{58}$ Thus, while they self-consciously sought to give spiritual comfort to the 'grossest sort' they sought to exact a price as well.

At this point it will be instructive as well as interesting to compare both the more pastoral and the more speculative approaches, which have been described up to this point, with the English translation of François du Jon's extraordinarily influential Revelation commentary. Du Jon or Junius ( $\left.1545^{-1602}\right)$ was a Huguenot scholar of the New Testament who settled in as part of the distinguished Heidelberg circle of Reformed theologians. In I596 his translated Latin commentary on the last book of the Bible was published in London by John Legat as The Apocalyps, or Revelation of S. Iohn the Apostle and Evangelist of our Lord Iesus Christ. ${ }^{59}$ Like the 'playn and easye'

55 Ibid. 272.

56 Ibid. I6.

57 Ibid, fo. A6v.

58 To similar effect see Scott McGinnis, "Subtiltie" exposed', 683-4.

59 First published in Latin as Apocalypsis S. Foannis apostoli et evangelist, methodica analysi argumentorum, notisque brevibus ad rerum intelligentiam \& catholic ac christian ecclesi historiam pertinentibus illustrata (Heidelberg, I59I). In I592 an English translation of the Apocalypse was published with Junius' notes in the margin as Apocalypsis: a briefe and learned commentarie upon the Revelation of Saint Iohn the Apostle and Evangelist, London 592 (RSTC I988) and a second edition of the same was printed as The Revelation of Saint Iohn the Apostle and Evangelist, London I594 (RSTC 2989). 
authors, du Jon goes to great length to draw out the pastoral implications of his work. ${ }^{60}$ Each chapter includes a section that examines the 'general' or 'profitable use' of that portion of the biblical text. For example, he sums up Revelation iv by exhorting his reader thus: 'Therefore having so goodly and necessary advertisements touching the grace of God... let us dayly acknowledge before god in all humilitie, that we are dead in ourselves, weake and ignorant. ${ }^{61}$ Similarly, du Jon emphasises the pastoral implications of the Seven Letters. He sums up their importance by noting that the salvation offered to the seven churches is 'in truth [offered] to all those Churches which Christ gathered together in this world by the ministerie of his servants'. ${ }^{62}$ Likewise, he assures his readers that those things that are given to the ancient Churches named therein are 'to remain \& belong as it were to all the members of the holy Catholike Church, that either are or shall be here below unto the end of the worlde'. ${ }^{63}$

Yet du Jon's work lacks the emphasis on the 'symple sort' of reader that is so characteristic of the 'playn and easye' writers. He makes no appeals to opening up Revelation to those without theological training. His work is not overly complicated but a programme of making it accessible does not stand out in the author's comments. It is a book intended to be read by ministers and theologians. If du Jon is somewhat more speculative than the pastoral authors, it tends to be a difference more in degree than in kind. ${ }^{64}$ Yet his focus on using Revelation to understand the history of the Church, especially the pernicious role of Gregory IX's Decretals, is more reminiscent of the speculative writers than Bullinger, Fulke, Gifford or Cartwright. ${ }^{65}$

If, then, a 'playn and easye' tradition of eschatological interpretation can be located in late sixteenth- and early seventeenth-century England, distinguishable even from continental writers with similar pastoral concerns, what was its significance? The increasing marginalisation of Puritans at court and their inability to gain royal and, by the time of Archbishop Whitgift, episcopal support for an ongoing reformation of the Church may help

The 1596 translation is the first version published as a discrete commentary, not as marginal notes.

${ }^{60}$ Junius was not alone among the Heidelberg theologians in emphasising this element in their eschatological writings. His colleague Jerome Zanchi exhibited very similar concerns in his writing on the subject. See John L. Farthing, 'Christ and the eschaton: the reformed eschatology of Jerome Zanchi', in W. Fred Graham (ed.), Later Calvinism: international perspectives, Kirksville, Mo I994, 333-54. Also note that a short treatise by Zanchi on the end of the world was translated into English by Henry Nelson and published as part of Speculum Christianum, or a Christian survey for the conscience, London I6I4 (RSTC 26121a.7).

61 The Apocalyps, or Revelation of S. Iohn the Apostle and Evangelist of our Lord Iesus Christ, London I596 (RSTC 2990), 5 o.

${ }^{62}$ Ibid. 7 .

${ }^{63}$ Ibid. $23-4$.

${ }_{64}$ See, for example, Junius' understanding of the significance of the general structure of Revelation (pp. 5I-2) and his discussion of the Number of the Beast (pp. I73-4).

${ }^{65}$ For example, ibid. IOI-3, I07, I73-4. 
explain why these writers increasingly concentrated on the reformation of the 'sympler sort' who were under their care and influence.

Here Gifford serves as a useful example. ${ }^{6}$ Having pressed forward through the 1570 os and 1580 s with his reforming agenda - organising synods and supporting Presbyterianism, writing against popular superstition, popery, witchcraft and, interestingly, the persecution of witchcraft - Gifford had his fingers badly burned in I584 when he was deprived of his living by Bishop Aylmer for nonconformity. His high-powered contacts at court - William Cecil, Francis Knollys and later Robert Devereux - proved ineffective in aiding him. Ecclesiastical opponents stymied the various attempts to regain his vicarage but eventually members of his former parish endowed a private lectureship for him, which enabled him to remain in Maldon until his death in i6oo.

What must have gone through the mind of this committed market-town minister seeking a further reformation and a better establishment, at least as he saw it, of the Church visible in his own country? Likely a fear that the Church of England as an institution was becoming a lost cause from a topdown perspective. Puritans like Gifford became more and more aware of the failure of English monarchs to complete the Reformation of their Church, a disappointment coupled with episcopal persecution. It is no wonder that their apocalyptic sensibilities, honed to a fine edge, eventually turned against the monarchy that they saw abandoning God.

In Gifford's day the divorce was not complete. Hence, in a spirit that seems far removed from his desire to comfort afflicted parishioners, his dedication to the earl of Essex encourages Devereux to play the role of a Protestant champion fighting to overcome the wicked forces of the papal AntiChrist. Essex, however, would prove a disappointing champion and increasingly Puritan hopes would be frustrated as fewer and fewer of their supporters at court wielded real power. Perhaps these issues help to explain Gifford's and like-minded individuals' pastoral concern with educating and edifying the 'common sort'. In so doing they cultivated the reformation of the mass of people who composed the English Church, from the bottom up.

It is ironic, then, that it was the writings of the more speculative apocalyptic authors that so captivated the imagination of the seventeenthcentury English reading public. Bullinger's and Gifford's books, meant to be consumed by all, went through two and three printings respectively;

${ }^{66}$ Pertinent biographical information may be derived from James Hitchcock, 'George Gifford and Puritan witch beliefs', Archiv für Reformationsgeschichte lviii (I967), 90-9; Alan MacFarlane, 'A Tudor anthropologist: George Gifford's discourse and dialogue', in Sydney Anglo (ed.), The damned art: essays in the literature of witchcraft, London $1977, \mathrm{I} 4 \mathrm{O}^{-} 55$; W.J. Petchey, A prospect of Maldon, I500-I689, Chelmsford I991, I87-234; and Scott McGinnis, George Gifford, 25-62. 
Cartwright's and Fulke's only one. The writings of Thomas Brightman and Joseph Mede, written for academics and originally composed in Latin, went through edition after edition after edition both in the original and, especially, in vernacular translation. ${ }^{67}$

Interestingly, du Jon's The Apocalyps, or Revelation of S. Iohn did have a much wider audience. From 1602 his commentary was incorporated into the margins of the Geneva Bible and from there his ideas exerted a tremendous influence on biblical interpretation in England and its American colonies for generations. ${ }^{68}$ The notes in the Geneva Bible, however, were there only to guide and direct readers in their interpretation of Scripture and space was at a premium. Significantly, the pastoral elements of du Jon's commentary, the portion of each chapter that he titled the 'general use', disappeared in the transition of his ideas from commentary to marginal notes.

Arthur Dent's The ruine of Rome went through eleven editions in the seventeenth century. ${ }^{69}$ Napier's $A$ plaine discovery went through five editions under that name, another seven under the slightly more exciting titles Napier's narration and The bloody almanack, and an additional ten between i6 I and I640 in translation on the continent. ${ }^{70}$ By the mid-seventeenth century, the readers of apocalyptic literature in England were looking in directions that offered more interesting ways to make sense of the religious and political complexities swirling about them than Bullinger, Fulke, Cartwright or Gifford were apparently able to offer. Yet if the market demanded multiple editions of the more speculative works of apocalyptic literature, it was only because the 'playn and easye' writers had emboldened early modern English readers to delve into Revelation. One wonders how many Puritan ministers were still

${ }^{67}$ Brightman's Revelation of the Apocalyps was published first in Latin (Frankfurt I6og) and then in English beginning with the r6I I Amsterdam edition and with subsequent editions in I6I5 and I6I6. At least twelve versions were subsequently published under various titles throughout the mid-seventeenth century. The introductory portions of Mede's Clavis apocalyptica were first published in Latin in 1627 . The full text quickly went through two editions in 1632 and another in 1649 . It was translated into English and published twice in I643, again in 1650 , and, under a slightly different title, in I657.

${ }^{68}$ Charles C. Butterworth, The literary lineage of the King James Bible, I340-I6II, Philadelphia I94I, I99.

69 Dent's The ruine of Rome was published in London in I603, I607, I6I I, I622 (twice), I628, I631, I633, I644, I650, and I656.

${ }_{70}$ Napier's A plaine discovery was originally to be published in Latin but in the wake of the events of ${ }_{15} 88$ he felt the need to publish in English so that his thoughts might be as accessible as possible before the Apocalypse. Firth speculates that he may also have felt the need to rush his book into print because his father-in-law had been implicated in the affair of the Spanish Blanks. A solidly Protestant book would go far in shoring up Napier's own reputation. It was published as A plaine discovery five times (Edinburgh I593, I6I I [twice], I645; London I594, I6II), twice in an abridged form as Napier's narration (London i642), five times as The bloody almanack under his name (London I645, I647 [twice], I649, I650), and three times as an abridgement by John Booker (London I643 [twice], I652). 
looking to Bullinger and Gifford for model sermons on the Apocalypse by the middle of the seventeenth century.

This article has explored an approach to the book of Revelation in sixteenth- and early seventeenth-century England that emphasised its usefulness as a pastoral tool. The larger goal, however, has been to indicate the degree to which interests in and expectations about the end times were part of the normative religious experience of early modern Englishmen and women and to suggest that the study of the Last Days plays a significant role in religious history because it gives the historian an opportunity to explore the assumptions of the ordinary and normative, not just the dramatic moments of chiliastic anxieties. 